\title{
NEW TESTAMENTES
}

\section{INSTRUCTIONS FOR CONTRIBUTORS}

\begin{abstract}
Submissions
Papers should be submitted via the following website: http://mc.manuscriptcentral.com/nts. Contributors are requested to send one electronic copy in Microsoft Word or Word Perfect and simultaneously a second copy in pdf format. If you experience any difficulties submitting your manuscript, please contact the Editor, Dr. Simon Gathercole atsjg1007@cam.ac.uk.
\end{abstract}

The author should certify that the article is not being submitted simultaneously to some other journal and explain to the editor the extent of any overlap with books or articles the author has published or is likely to publish in the near future. Articles that appear elsewhere in the same or a different language should not be submitted to this journal.

In order to ensure an anonymous reviewing process, contributors are expected to ensure that material submitted bears no indication of their identity either at the head of the article or in references to their own work in the text or footnotes.

Upon acceptance of a paper, the author will be asked to assign copyright (on certain conditions) to Cambridge University Press.

Contributors are responsible for obtaining permission to reproduce any material in which they do not hold copyright and for ensuring that the appropriate acknowledgements are included in their manuscript.

\section{Manuscript preparation}

New Testament Studies accepts contributions in English, French and German. All articles submitted for publication in this journal are expected to conform to the requirements of the full instructions for contributors, which can be found at http://assets.cambridge.org/NTS/NTS_ifc.pdf

Submissions should not normally be longer than 8,500 words, including footnotes (i.e. about 20 pages of the current NTS format). All materials should be double-spaced, including footnotes and citations. Special materials (e.g. lists, tables, charts, diagrams) should be typed on sheets separate from the main text, and the location of such material in the main text should be indicated clearly (e.g. 'insert chart 1 here'). Contributors are asked to supply an abstract of their article, not exceeding 100 words in length, and a list of up to six keywords (for on-line searching). Short studies may be supplied without an abstract.
On acceptance of a submission, contributors will be asked to send a final form of the article electronically in both word format (Microsoft Word or Word Perfect) and pdf format; they will also be asked to supply a copy of any font used in the article. They will be expected to check and correct first proofs of their article after it has been typeset.

\section{Proofs}

Typographical or factual errors only may be changed at proof stage. The publisher reserves the right to charge authors for correction of non-typographical errors.

Authors of articles and short studies will receive a pdf file of their contribution and a complimentary issue upon publication.

This journal issue has been printed on FSC-certified paper and cover board. FSC is an independent, non-governmental, not-for-profit organisation established to promote the responsible management of the world's forests. Please see www.fsc.org for information.

\section{(C) Cambridge University Press 2020}

CAMBRIDGE UNIVERSITY PRESS

University Printing House, Shaftesbury Road,

Cambridge св2 8Bs, United Kingdom One Liberty Plaza, Floor 20, New York, NY 10006, USA 477 Williamstown Road, Port Melbourne, vic 3207, Australia Ruiz de Alarcón 13, 28014, Madrid, Spain

Dock House, The Waterfront, Cape Town 80o1, South Africa

Printed in Great Britain by Bell \& Bain Ltd., Glasgow. 


\section{NEW TESTAMENTES}

\section{Articles}

Brent Nongbri Palaeography, Precision and Publicity: Further Thoughts on P.Ryl. III.457 (P52) [471-499]

\section{Thomas Schmeller Dissimulatio} artis? Paulus und die antike Rhetorik [500-520]

Christophe Guignard Hermann von Soden, Alfred Schmidtke et les manuscrits de Bérat [521-533]

Susan E. Hylen Public and Private Space and Action in the Early Roman Period

\section{[534-553]}

Thомаs P. Dixon Judgement for Israel: The Marriage of Wrath and Mercy in Romans 9-11

[565-581]

Charles Nathan Ridlehoover The Logic of Matthew 6.19-7.12: Heavenly Priorities in the Kingdom of Earth [582-60o]

Brandon Massey Translating, Summarising and Hidden Attribution: R. H. Lightfoot's Problematic Use of German Scholarship [601-629]

Books Received 2019-20 [630]
A. D. Macdonald To Save Whom They
Can: Another Look at Philo and
Missionary Deceit
[554-564] 